\title{
DEVELOPING AN ATLAS BASED ON FROND VENATION PATTERNS ANALYSIS OF POLYPODIALES IN TARAKAN
}

\author{
Fadhlan Muchlas Abrori* and Aidil Adhani \\ Department of Biology Education, University of Borneo Tarakan, Indonesia \\ *corresponding e-mail: fadhlan1991@gmail.com
}

\begin{abstract}
This study aims to identify and analysis of frond venation pattern of Polypodiales in Tarakan, which then developing an atlas based on the results obtained. The results of identify and analysis the frond venation pattern of Polypodiales showed that there were 14 species of Polypodiales. The venation pattern found in Polypodiales were reticulate and open forked. While in the development of an atlas, the assessment result of the content feasibility aspect by the content expert obtained $90.77 \%$ (valid), and assessment result of the presentation feasibility aspect obtained 100\% (valid). The assessment result of the book size aspect by the media expert obtained $90 \%$ (valid), while assessment result of the book cover design aspect obtained $93.33 \%$ (valid), and assessment result of the content book design obtained $91.42 \%$ (valid). The assessment result of the language usage by language expert obtain $92 \%$ (valid), and assessment result of the language accuracy obtained $96 \%$ (valid). The field assessment result by lecturer for the easiness aspect obtained $92.31 \%$ (valid), the attractiveness aspect obtained $100 \%$ (valid), and the understandable aspect obtained $90 \%$ (valid). Meanwhile, the field assessment result by student for the easiness aspect obtained $97.43 \%$ (valid), the attractiveness aspect obtained $93.33 \%$ (valid), and the understandable aspect obtained $100 \%$ (valid).
\end{abstract}

Keywords: atlas, ferns venation pattern, Polypodiales

(C) 2017 Department of Biology Education, FTTE, University of Muhammadiyah Malang, Indonesia

\section{INTRODUCTION}

Fern (Pterydophyta) is one of the plant divisions that is spreaded in the world, especially in the tropics (Oloyede, 2012). Ferns are important component for the ecosystem, especially in tropical rain forest areas (Zhang et al., 2014). Ferns are also an important terrestrial plant first thought to have emerged 400 million years ago (Haou et al., 2011). Ferns (Pterydophyta) are group of plants which have the greatest diversity (Vasco et al., 2013). This been estimated that there are approximately 20.000 species, with 225 genera (genus) of ferns around the world (Prosea. 2003 within Aminasih et al., 2013; Prastyo et al., 2015), in which the 4,000 species of them exist in Indonesia, Philippines, Papua New Guinea, and northern Australia (Whitten and Whitten. 1995 within Aminasih et al. 2013). In addition, the 3,000 species of those 4,000 ferns are distributed in Indonesia (Loveless, 1995 within Jannah et al. 2015).
Fern is a plant that has a lot of diversity in Indonesia (Arini and Kinho, 2012). One of the ordo which has high diversity is Polypodiales. Smith et al. (2006) stated that the Polypodiales ordo on fern has 15 families, including: Polypodiaceae, Davalliaceae, Oleandraceae, Tectariaceae, Lamariopsidaceae, Dryopteridaceae, Onocleaceae, Blechnaceae, Thelypteridaceae, Woodsiaceae, Aspleniaceae, Dennstaedtiaceae, Saccolomataceae, and Lindsaeaceae.

Sujalu (2007) found that there were $88.89 \%$ of epiphytic ferns in Malinau Research Forest which were belong to Polypodiales group. Similarly, Supu and Munir (2009) also revealed that as much as $81.82 \%$ of ephypitic plant in the forest around Lake Lawulamoni in Kabawo Region were Polypodiales. Another research conducted by Dewa et al. (2012) about inventory and characterization of ferns in Bukit Sebubus Tourism Area in West Kalimantan noted that there were $50 \%$ of ferns were Polypodiales, which is in line with Arini and Kinho (2012) who found that approximately 
$81.82 \%$ of ferns in Gunung Ambang Conservation Area were Polypodiales.

Polypodiales are characterized by various venations which differentiate each other. Venation patterns are one of the biometric feature of plants (Satyanuraga, 2015; Wahyumianto et al., 2012). The venation pattern similarity indicates genetic relationship among ferns species (Satyanuraga, 2015). In addition, the frond venation patterns in fern also show its evolutionary characteristic (Vasco et al., 2013).

The research results of venation pattern can be developed to be learning media to provide additional knowledge to students, especially in fern identification. The initial observation on students who have taken Plant Morphology and Plant Taxonomy class expeienced problem in their texbooks which are less contextual and pictures on the textbooks only consist of illustrations rather than real pictures. Observation and interview on those students showed that there were about $89.8 \%$ of students required more contextual teaching media that also contained many real pictures.

Based on observation and student interview, one of the media that can be developed is atlas. Atlas contains pictures of the elements of information which is selected and described deeper and more detailed for a specific purpose (Nurdin, 2015). The selection of atlas learning in the development of research results is because the atlas is one of the learning materials that emphasizes on the graphic aspect, easy to used as a reference in identification. Graphics aspects in atlas also can increase the student motivation in learning. Tutut (2016) state that the purpose of using atlas is to improve conceptual understanding of the user based on the material and description aspect in detail. Research related to the developing of atlas has been done by Solikhah (2015), it showed that the development of the atlas as a learning media obtained chi-square values for peer reviewers and practitioners of 44.6 and 36.5 with good criteria.

Therefore, it is important to produce an atlas that can help students studyplant morphology and plant taxonomy easily. This atlas is expected to be supporting learning media that can provide contextual data so that students are able to do field identification.

\section{METHOD}

This is research and development study. The development model in this research and development used modified development FourD model based on Thiagarajan et al. (1974). This model consisted of four stages of development, that consist of: define, design develop, and disseminate. In this research and development, the development model was only until the stage of development (develop).

This research consisted of two stages. The first stage was the research stage, consist of: inventory and identification of ferns of Polypodiales ordo and conducting venation pattern analysis. The second stage was the stage of developing the research results into Atlas Learning.

\section{Research Stage}

The research stage in this research consisted of two parts, namely: 1) inventory and identification; 2) venation pattern analysis.

\section{Inventory and Identification}

Inventory of ferns was done by exploration refering to Hartini within Nasari (2012). Exploration means investigating the whole location, that represent the ecosystem and vegetation types of research area. There are 4 locations for this research that consist of conservation forest in Tarakan (Amal Forest, Gunung Belah Forest, Research Forest of Borneo Tarakan University and Juata Conservation Forest).

The sample was selected based on purposive sampling (Lubis, 2009). The samples were collected based on the existence of ferns which considered the represent area. When one species found more than one, it wouldn't be collected because it has represented the ferns that has been found.

The next step was making herbariums. The herbarium making was aimed to preserve the fern, so it would be easier to observe the characteristics of the ferns. The herbarium making referred to the procedure by Storrie (2009), Victor et al (2004) and Greening Australia (2012). The identification of the species of ferns referred to Sporne (1962), Piggot (1998), Kinho (2009), Tjitrosoepomo (2008) and Stenis (2008). 


\section{Venation Pattern Analysis}

Venation pattern analysis on ferns referred to Ash et al, (1999), Hoshizaki and Moran (2001) and Simpson (2010). The observation of the venation pattern could be done by using stereo microscope to get detail picture of venation pattern of each frond in ferns.

\section{Development Stage}

The development stage in this research consisted of defining stage, designing stage; and developing stage.

\section{Defining Stage}

Defining stage is the stage for establishing and defining the requirements of the learning. The defining stage included five main steps, namely: front-end analysis, learner analysis, task analysis, concept analysis and specifying instructional objectives. The details of each step in the define stage are presented in Table 1.

Table 1. Details of the steps on the defining stage

\begin{tabular}{|c|c|}
\hline Stage & Description \\
\hline a. Front End Analysis & $\begin{array}{l}\text { Identifying students problem, especially on the academic aspects related to the } \\
\text { material about the venation patterns and the classification of ferns }\end{array}$ \\
\hline b. Learner Analysis & $\begin{array}{l}\text { Measuring the students basic knowledge with tests, interviews and } \\
\text { questionnaires }\end{array}$ \\
\hline c. Concept analysis & $\begin{array}{l}\text { The standard competences to be achieved in learning are: } \\
\text { - Understanding the principles of analyzing the vanation patterns ferns } \\
\text { Basic Competencies to be achieved are } \\
\text { - } \quad \text { Describing the types of venation patterns of ferns } \\
\text { - Distinguishing venation patterns on different types of fern }\end{array}$ \\
\hline d. Task Analysis & $\begin{array}{l}\text { Tasks include structured tasks on the identification of venation patterns in plants } \\
\text { and genetic relationship analysis based on venation patterns }\end{array}$ \\
\hline $\begin{array}{l}\text { e. Specifying instructional } \\
\text { objectives }\end{array}$ & $\begin{array}{l}\text { The instructional objectives are } \\
\text { - Students are able to explain the types of venation patterns of ferns through } \\
\text { proper discussion and literature study } \\
\text { - Students are able to distinguish the venation pattern of at least } 10 \text { leaf types } \\
\text { through field observation sheet }\end{array}$ \\
\hline
\end{tabular}

\section{Designing Stage}

The designing stage aimed to design learning materials. This stage consists of 4 steps, namely: 1) criterion-test construction; 2) media selection; 3) format selection, which examines the formats of the existing learning materials and determining the formats of learning materials to be developed; 4) making the initial design according to the formats determined. The details of each step in the designing stage are shown in Table 2.

\section{Developing Stage}

The developing stage is the stage to develop product, consists of 2 steps, namely: a) expert appraisal followed by the revision; b) developmental testing. The detail of each step in the development stage are shown in Table 3.

There are two data types in this research, namely: research data and product assessment data. The research data is qualitative data about the venation patterns of Polypodiales. The data were then developed into atlas. The product assessment data include quantitative and qualitative data. The quantitative data include the assessment from the validators and students, while the qualitative data are responses and suggestions from the validators and students.

The data of plant species and frond venation have been collected through taking notes of fern patterns and documenting the fern patterns (morphological characteristics on frond venation). Furthermore, the validation of the media has been done by expert validator on several aspects using a questionnaire that consist of aspects presented in Table 4.

The developmental testing (field test) has been done by practitioners and students on several aspect using questionnaire that consists of aspect presented in Table 5 . 
Table 2. Details of the steps in the designing stage

\begin{tabular}{ll}
\hline \multicolumn{1}{c}{ Stage } & \multicolumn{1}{c}{ Description } \\
\hline a. criterion test construction & The task in the atlas are placed at the end of each chapter \\
b. media selection & Atlas is the product of this research \\
c. format selection & The atlas content consist of: the introduction part, the main part and \\
the closing part. & The initial design is the design of all learning materials that must be \\
done before expert appraisal and developmental testing
\end{tabular}

Table 3. Details of the steps in the developing stage

\begin{tabular}{ll}
\hline \multicolumn{1}{c}{ Stage } & Description \\
\hline a. Expert appraisal & The expert appraisal on the learning materials includes: materials, \\
& media and language \\
b. Developmental testing & The field developmental testing is carried out to obtain direct \\
& feedback in the form of responses, reactions, comments of the \\
& students, and practitioners of the learning materials that have been \\
& developed. The sample in this stage was 40 students that has taken \\
& plant morphology and plant anatomy. Those sample were selected \\
& using purposive sampling that is based on student's grades (low, \\
& medium, and high).
\end{tabular}

Table 4. Expert appraisal aspect

\begin{tabular}{cl}
\hline \multicolumn{1}{c}{ Validators } & \multicolumn{1}{c}{ Aspect } \\
\hline Content Expert & Feasibility of Content \\
& Feasibility of Presentation \\
Media Expert & Book Size \\
& Cover design \\
& Content book design \\
Language Expert & Language Usage \\
& Language Accuracy \\
\hline
\end{tabular}

Table 5. Developmental testing aspect

\begin{tabular}{ll}
\hline \multicolumn{1}{c}{ Evaluators } & \multicolumn{1}{c}{ Aspect } \\
\hline Practitioners & Easiness \\
& Attractiveness \\
Students & Understandable \\
& Easiness \\
& Attractiveness \\
& Understandable \\
\hline
\end{tabular}

In the validation questionnaire, the questionnaire used Likert scale with alternative options 1-5. The validation questionnaire was used to analyze the quantitative data by calculating the answer percentage. Thus, the percentages were computed by employing equation (1).

$\mathbf{P}=\frac{2 x}{\sum x_{i}} \times 100 \%$

Description:

$$
\begin{aligned}
& \mathrm{P}=\text { percentage } \\
& \sum x=\text { The number of respondents in } 1 \text { item } \\
& \sum x i=\text { ideal score in the item } \\
& 100 \%=\text { constan (Arikunto, 2002) }
\end{aligned}
$$

The criteria of validity of the validator assessment was determined based on percentage criteria in Table 4.

Table 6. Criteria percentage of assessment questionnaire

\begin{tabular}{ll}
\hline \multicolumn{1}{c}{ Percentage } & \multicolumn{1}{c}{ Description } \\
\hline $85,94-100 \%$ & Valid (Revision not \\
& required/minor revision) \\
$67,18-85,93 \%$ & Enough (minor revision) \\
$48,44-67,17 \%$ & Deficient (major revision) \\
$25-48,43 \%$ & invalid (major revision) \\
\hline Source: Suryabrata (2002) within Ismail (2007)
\end{tabular}

\section{RESULTS AND DISCUSSION}

\section{Venation Pattern Analysis}

The results of the research related to the inventory, identification and venation pattern analysis of ferns found are presented based on Table 7.

The ferns that has been found then grouped based on Polypodiales and the others. The result shows that there are 14 species of Polypodiales. The ferns found are grouped based on families that is included in polypodiales ordo and outside polypodiales ordo. Based on the results of the ferns collected, there are 14 species of ferns belonging to the families of polypodiales.

The data shows that families Aspleniaceae, Blechnaceae, Davalliaceae and Lomariopsidaceae have no variation on their venation pattern. Conversely, on families Polypodiaceae and 
Pteridaceae have various venation pattern (Table 6).

Tabel 7. Venation pattern of fern in Tarakan area

\begin{tabular}{clll}
\hline No & \multicolumn{1}{c}{ Family } & \multicolumn{1}{c}{ Species } & \multicolumn{1}{c}{ Venation Pattern } \\
\hline 1 & Aspleniaceae & Asplenium nidus L. & Open-forked \\
2 & Blechnaceae & Blechnum orientale L. & Open-forked \\
& & Stenochlaena palustris (Burm.f.) Bedd. & Open-forked \\
3 & Davalliaceae & Davallia denticulata (Brum) Mett & Open-forked \\
4 & Lomariopsidaceae & Nephrolepis sp. & Open-forked \\
5 & Polypodiaceae & Drymoglossum piloselloides (L.) Presl. & Reticulate \\
& & Drynaria quercifolia $($ L.) J.Sm. & Reticulate \\
& & Dryopteris filix-mas $($ L.) Schott. & Open-forked \\
& & Pyrrosia piloselloides $($ L.) M.G. Price. & Can't be determined \\
6 & Pteridaceae & Acrostichum aureum L. & Reticulate \\
& & Adiantum trapeziforme L. & Open-forked \\
& & Adiantum venustum D.Don. & Open-forked \\
& & Pityrogramma calomelanos L. & Open-forked \\
& & Pteris vitata L. & Open-forked \\
\hline
\end{tabular}

The venation variations on these families (Polypodiaceae and Pteridaceae), show the useful characteristic for identification (Figure 1 and 2). For example, the venation pattern of Polypodiaceae on Drymoglossum, and Drynaria is reticulate, while the venation of Dryopteris is open-forked. In Pyrrosia, the venation can not be determined. Probably, it is caused by the pattern that is too thin. For example, the venation patterm of Pteridaceae on Acrosticum is reticulate, while the venation of Pteris, Adiantum and Pityrogramma is open-forked.

The classification of ferns family has been done based on Smith et al. (2006). Some research on fern classification also been done by Christenhusz et al., (2010). He found that the genus of Dryopteris on ordo Polypodiaceae considered as separated family, which is Dryopteridaceae. The genus Nephrolepis is also considered as the family of Nephrolepidaceae. This research is using Smith et al classification because this classification is widely used by researchers on fern study. According to Christenhusz et al., (2010) classification however, variation of frond venation only found in Pteridaceae, while in polypodiaceae there are no variation.

Generally, frond venation on fern can be used in classification and identification process. Most of ferns have pinnate venation form, with central vein then becomes veinlets on each sides. There are few of ferns that have palmate venation. Palmate venation is a venation that has many central veins that come up from the frond base. However, the most important thing on the venation form of ferns is the vein patterns (the smallest vein) or vein segment. There are two kinds of venations ased on the general pattern, which are opened venation and closed venation. The opened venation pattern is the pattern that the veinlets from the central vein are not connected each other. This type of venation consists of two types, which are simple and open-forked. Furthermore, the reticulate (closed venation) is the pattern that its veinlets from central vein connect and become nett-like (Simpson, 2010).

\section{Developing of Atlas}

The defining stage on front end analysis has been found that students experienced difficulties in understanding plant species, especially ferns. This is because of the lack contextual of textbooks that they use. On the stage on learner analysis, interviewed on some students found that about $89.8 \%$ of 40 sudents needed contextual learning media that consists of many real pictures.

Furthermore, the result of front end analysis then can be arranged to be competence standard and basic competencies. The standard competences that should be achieved in learning are: understanding the principles of analyzing the vanation patterns ferns. Basic Competencies to be achieved are:

1. Describing the types of venation patterns of ferns 
2. Distinguishing venation patterns on different types of fern

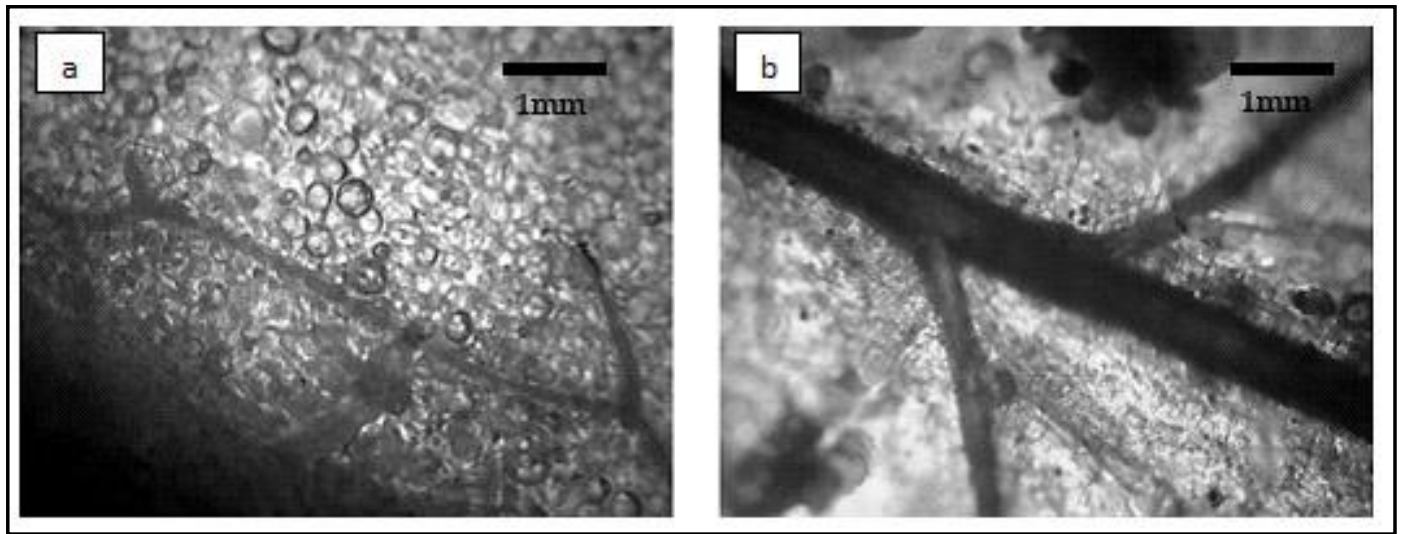

Figure 1. Venation Variation on Polypodiaceae. a) Drymoglossum with nett-like venation (reticulate), closed type venation; b) Drynaria with open-forked venation

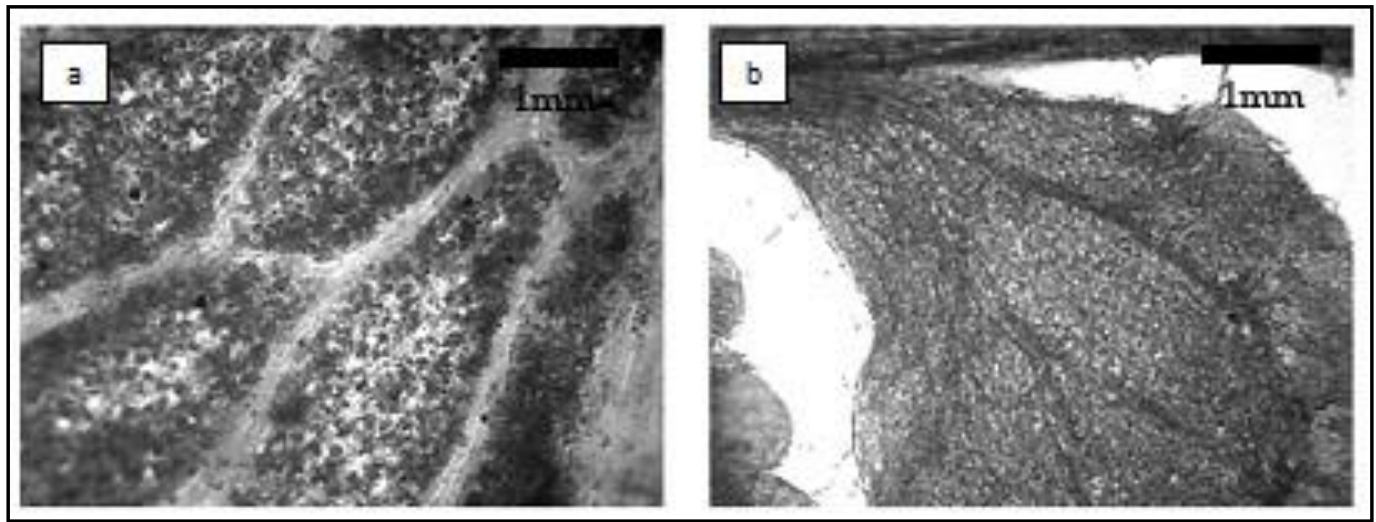

Figure 2. Venation Variation on Pteridaceae. a) Acrosticum with nett-like venation (reticulate), closed type venation; and b) Adiantum with open-forked venation

Furthermore, the result of concept anaysis then becomes tasks on the learning media that will be developed on the task analysis. Tasks on this media are designed as independent tasks such as field study related to the introduction of ferns.

The next step is specifying instructional objectives that have been arranged based on concept analysis dan task analysis. On this step, the learning instructional has been made as follow:

1. Students are able to explain the types of venation patterns of ferns through proper discussion and literature study

2. Students are able to distinguish the venation pattern of at least 10 leaf types through field observation sheet

On the designing stage, each task are designed to be placed at the end of the chapter and has been arranged based on standard competencies and basic competencies, indicators, and learning objectives. According to some considerations on defining stage, then visual media on the form of atlas has been selected as a learning media that is aimed to provide detail visualization on plant morphology through fern pictures on Tarakan for students. The atlas that has been made consists of introduction (basic materials), main materials that consist of fern pictures of Tarakan, and the closing part.

Developing the atlas requires validation and field test to make sure the quality of product. Validation includes: validation by material expert, media expert, and language expert. Field tests include practitioner (lecture) and students. Briefly, the quality of atlas learning is presented in Table 8.

The assessment result of the feasibility content, by material expert, was $90.77 \%$ (valid); 
while the presentation feasibility aspect achieved $100 \%$ (valid). The content expert stated that the atlas is very good and has no mistake on the material. It consists of basic material that is related to venation patterns, while the core material consists of the research results of the ferns venation (Figure 3 and 4).

Table 8. Quality of Atlas Learning

\begin{tabular}{|c|c|c|c|}
\hline No & Aspect & Percentage & Information \\
\hline & Content Expert & & \\
\hline 1 & $\begin{array}{l}\text { Feasibility of } \\
\text { Content }\end{array}$ & 90.77 & Valid \\
\hline \multirow[t]{2}{*}{2} & $\begin{array}{l}\text { Feasibility of } \\
\text { Presentatio }\end{array}$ & 100 & Valid \\
\hline & Media Expert & & \\
\hline 1 & Book Size & 90 & Valid \\
\hline 2 & Cover design & 93.33 & Valid \\
\hline \multirow[t]{2}{*}{3} & $\begin{array}{l}\text { Content book } \\
\text { design }\end{array}$ & 91.42 & Valid \\
\hline & Language Exper & & \\
\hline 1 & $\begin{array}{l}\text { Language } \\
\text { Usage }\end{array}$ & 92 & Valid \\
\hline \multirow[t]{2}{*}{2} & $\begin{array}{l}\text { Language } \\
\text { Accuracy }\end{array}$ & 96 & Valid \\
\hline & Lecturer & & \\
\hline 1 & Easiness & 92.31 & Valid \\
\hline 2 & Attractiveness & 100 & Valid \\
\hline \multirow[t]{2}{*}{3} & Understandable & 90 & Valid \\
\hline & Student & & \\
\hline 1 & Easiness & 97.43 & Valid \\
\hline 2 & Attractiveness & 93.33 & Valid \\
\hline 3 & Understandable & 100 & Valid \\
\hline
\end{tabular}

Assessment from language expert on language usage aspect obtained $92 \%$ (valid) and the language accuracy obtained $96 \%$ (valid). Therefore, the language for this atlas is very accurate.

Assessment result of book size aspect by media expert obtained $90 \%$ (valid), assessment result of book cover design obtained $93.33 \%$ (valid), and assessment result of book content design obtained $91.42 \%$ (valid). The composition of the atlas cover consist of fern image from the research (Figure 3). The composition of the atlas content consist of fern images with details explanation fern parts. (figure 4).

The expert validation stage has very important role in developing learning atlas because it consists of the whole quality of learning media content. Learning atlas as one of learning media shoud be validated thoroughly.
According to Depdiknas (2006), learning media is a set of materials/ content that has been arranged systematically, either written or not, in order to achieve condusive learning environmental for learners. This can be related to stages on learning media selection, which are: a) learning materials should support in achieving standard competencies and basic competencies, b) aspects identification on standart competencies and basic competencies, c) identification of learning materials, d) selecting relevant materials to the standard competencies and basic competencies, and e) selecting learning sources.

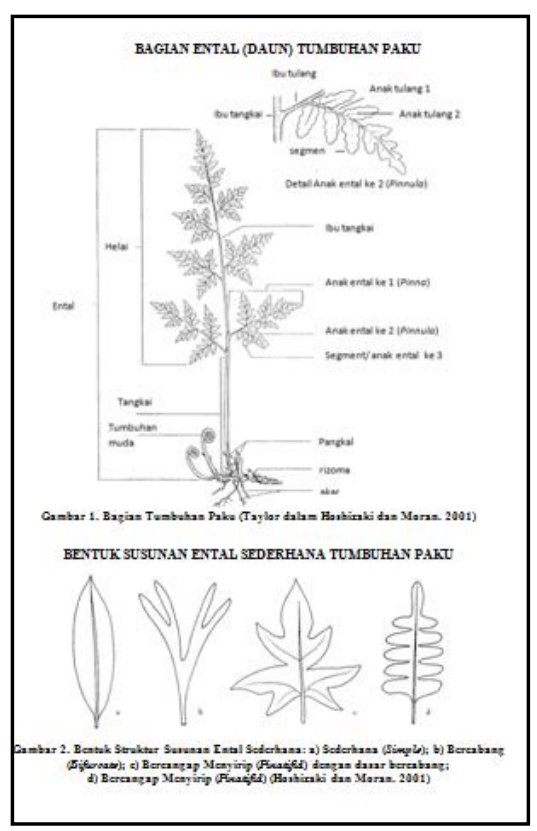

Figure 3. Basic Material

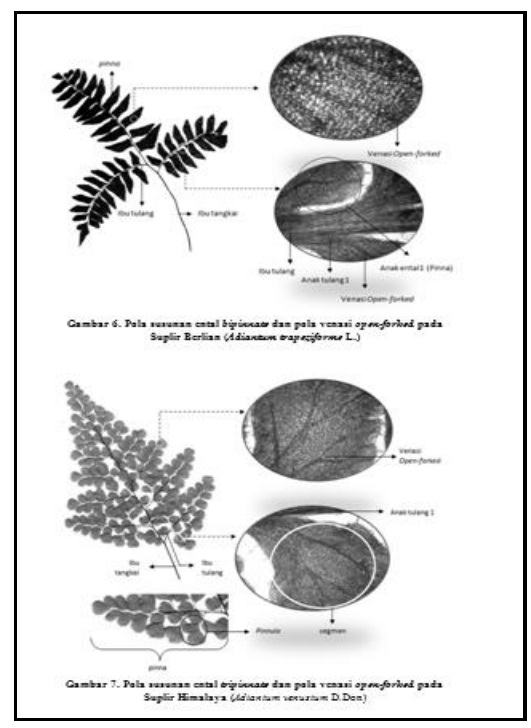

Figure 4. Core Matterial 


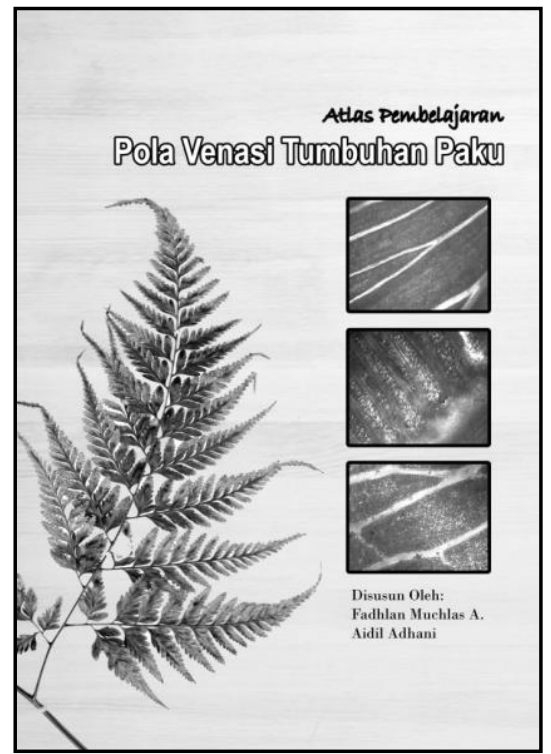

Figure 5. Atlas Cover

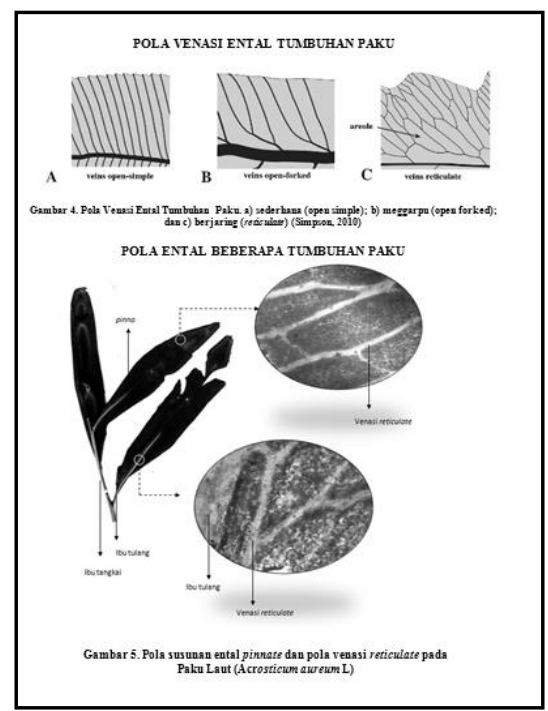

Figure 6. Atlas Content Layout

Field assessment result from practitioner on easiness aspect obtained $97.43 \%$ (valid), attractiveness aspect obtained $100 \%$ (valid) and understanding aspect obtained $90 \%$ (valid). On the other hand, field assessment result from students on easiness aspect obtained $97.43 \%$ (valid), attractiveness aspect obtained $93.33 \%$ (valid) and understanding aspect obtained $100 \%$ (valid). Based on inputs and suggestions, it is found that students prefer atlas because it emphasizes on the visual elements, so that students can more easily understand the material.

Finally, the field test has been done to obtain direct responses, reaction, student comments, and practitioners on the learning media that has been developed. Thiagarajan, et al., (1974) says that field test, revision, and refield test should be done to achieve consistent and effective learning media to use.

\section{CONCLUSION}

Based on the result and discussion, it can be concluded that: (1) there were 14 species of ferns belonging to the families of Polypodiales ordo. The venation pattern of ferns found is reticulate and open forked. (2) The venation pattern found in Polypodiales were reticulate and open forked. The assessment result of the content feasibility aspect by the content expert obtained $90.77 \%$ (valid), and assessment result of the presentation feasibility aspect obtained $100 \%$ (valid). The assessment result of the book size aspect by the media expert obtained $90 \%$ (valid), while assessment result of the book cover design aspect obtained $93.33 \%$ (valid), and assessment result of the content book design obtained $91.42 \%$ (valid). The assessment result of the language usage by language expert obtain $92 \%$ (valid), and assessment result of the language accuracy obtained $96 \%$ (valid). The field assessment result by lecturer for the easiness aspect obtained $92.31 \%$ (valid), the attractiveness aspect obtained $100 \%$ (valid), and the understandable aspect obtained $90 \%$ (valid). Meanwhile, the field assessment result by student for the easiness aspect obtained $97.43 \%$ (valid), the attractiveness aspect obtained 93.33\% (valid), and the understandable aspect obtained $100 \%$ (valid).

The developing learning media in every research is very important to be implemented. The learning media will have a contribution to teaching and learning in classroom. The abundance of local potential in every region in Indonesia can be developed into a learning material in all levels of education.

Further research that can be done is finding out the effectivity of the learning atlas on the improvement of student learning achievement in the teaching and learning process.

\section{REFERENCES}

Aminasih, N., Marisa, H. \& Harmida. (2013, Februari) Inventarization of pteridophytes plants species in Sriwijaya University Campus Area, Indralaya, South Sumatera. Paper presented at 4th International Conference on Global Resource Conservation \& 10th Indonesian Society for 
Plant Taxonomy Congress. Brawijaya University

Arikunto, S. (2002). Prosedur penelitian suatu pendekatan praktek (Edisi revisi). Jakarta: Rineka Cipta.

Arini, D. I. D., \& Kinho, J. (2012). Keanekaragaman jenis tumbuhan paku (pteridophyta) di cagar alam Gunung Ambang Sulawesi Utara. Info BPK Manado, 2(1), $17-40$

Ash, A., Ellis, B., Hickey, L. J., Johnson, K., Wilf, P., \& Wing, S. (1999). Manual of leaf architecture - morphological description and categorization of dicotyledonous and netveined monocotyledonous angiosperms. Washington: Leaf Architecture Working Group. Department of Paleobiology Smithsonian Institution.

Christenhusz, M. J. M., Zhang, X. C., \& Schneider, H. (2011). A linear sequence of extant families and genera of lycophytes and ferns. Phytotaxa, 19, 7-54.

Depdiknas. (2006). Pedoman memilih dan menyusun bahan ajar. Jakarta: DepdiknasDirtjen Dikdasmen

Dewa, E.T., Listiawati, A, \& Darussalam. (2012). Inventarisasi dan karakterisasi tumbuhan paku di kawasan wisata alam Bukit Sebubus Kalimantan Barat. Jurnal Sains Mahasiswa Pertanian, 1(1), 1-10

Greening Australia (2012) Collect, prepare, and preserve plant specimens. Australia: Aboriginal Landcare Education Program. Australian Government.

Haou, S., Belair, G., \& Viane, R. L. L. (2011). Inventory of the fern (filicopsida) of numidia's (North-Eastern Algerian). International Journal of Biodiversity and Conservation, 3(6), 206-223

Hoshizaki, B. J. \& Moran, R. C. (2001). Fern grower's manual. Portland, Oregon: Timber Press.

Ismail, T. (2007). Pengembangan modul ekosistem untuk pembelajaran sains di SMP kelas VII dengan model siklus belajar (learning cycle) yang berorientasikan konstruktivisme. (Unpubished Thesis). Universitas Negeri Malang.

Jannah, M., Prihanta, W. \& Susetyorini, E. (2015). Identifikasi pteridophyta di piket nol Pronojiwo Lumajang sebagai Sumber Belajar Biologi. Jurnal Pendidikan Biologi Indonesia, 1(1), 89-98.

Kinho, J. (2009). Mengenal beberapa jenis tumbuhan paku di kawasan hutan payahe
Taman Nasional Aketajawe Lolobata Maluku Utara. Manado: Balai Penelitian Kehutanan Manado.

Lestari, T. P. (2016). Analisis karakteristik ekstrak betasianin kulit buah naga hylocereus polyrhizus dan hylocereus undatus serta uji stabilitas organoleptik jelly sebagai media pembelajaran atlas. Jurnal Pendidikan Biologi Indonesia, 2(1), 78-87.

Lubis, S. R. (2009). Keanekaragaman dan pola distribusi tumbuhan paku di hutan wisata alam Taman Edeng Kabupaten Toba Samosir Provinsi Sumatera Utara. (Unpublished Thesis). Medan: Universitas Sumatera Utara.

Nasari, S., \& Ruqiah. (2012). Pembuatan flipchart dari hasil inventarisasi tumbuhan paku di hutan adat desa Teluk Bakung. (Unpublished Thesis). Tanjungpura: Biology Education Department, FKIP Untan

Nurdin, Y. (2015). Peta, atlas dan globe dalam pembelajaran IPS. Retrieved from http:// sumsel.kemenag.go.id.

Oloyede, F. A. (2012). Survey of Ornamental Fern, Their Morphology and uses for environmental protection, improvement and management. Ife Journal of Science, 14(2), 245-252.

Piggot. (1998). Fern of Malaysia. Kuala Lumpur: Tropical Press.

Prastyo, W. R., Heddy, S. \& Nugroho, A. (2015). Identifikasi paku epifit pada batang tanaman kelapa sawit (Elaeis guineensis J.) di Lingkungan Universitas Brawijaya. Jurnal Produksi Tanaman, 3(1), 65 - 74

Satyanuraga, D. (2015). Penerapan vektor dalam pengelompokan tanaman berdasarkan bentuk tulang daun. (Published Article). Bandung: Institut Teknologi Bandung.

Simpson, M. G. (2010). Plant systematics. $2^{\text {nd }}$ Edition. Cambridge, Massachusetts: Elsevier-Academic Press.

Smith, A. R., Pryer, K. M., Schuettpelz, E., Korall, P., Schneider, \& Wolf, P. G. (2006). A classification for extant ferns. Taxon, 55(3), 705-731

Solikhah, A. N. (2015). Atlas keanekaragaman angiospermae sekitar sekolah dan pengembangan LKS inkuiri terbimbing untuk SMA/MA. (Unpublised Thesis). Yogyakarta: UIN Sunan Kalijaga Yogyakarta.

Sporne. K. R. (1962). The morphology of pteridophytes. London: Hutchinson \& Co. 
Stenis, C. G. G. V. (2008). Flora. Jakarta: Pradnya Paramita.

Storrie, A. (2009). Collecting and preparing plant for identification. New South Wales: Primefact. State of New South Wales through Department of Industry and Investment.

Sujalu, A. P. (2007). Analisis vegetasi keanekaragaman paku - pakuan (pteridophyta) epifit pada hutan bekas tebangan di Hutan Penelitian Malinau (HpmCifor Seturan). RIMBA Kehutanan Fakultas Kehutanan Unmul, 12(1), 1-10.

Supu, H., \& Munir, A. (2009). Jenis-jenis tumbuhan epifit di hutan kawasan sekitar danau Lawulamoni Kecamatan Kabawo kabupaten Muna. WARTA-WIPTEK, 17(2), 101-106.

Thiagarajan, S., Semmel, D. S. \& Semmel, M. I. (1974). Instructional development for training teachers of expectional children. Minneapolis, Minnesota: Leadership
Training Institute / Special Education, University of Minnesota.

Tjitrosoepomo, G. (2008). Taksonomi umum. Yogyakarta: UGM Press.

Vasco, A., Moran, R. C., \& Ambrose, A. (2013). The evolution, morphology and development of fern leaves. Frontiers in Plant Science, 4, 1 -16

Victor, E. J., Koekemor, M. \& Fish, L. (2004) Herbarium essentials. South Africa: The Project Coordinator Southern African Botanical Diversity Network.

Wahyumianto, A., Purnama, I. K. E., \& Christyowidiasmoro. (2012). Identifikasi tumbuha berdasarkan minutae tulang daun menggunakan SOM Kohonen. (Published Article). Surabaya: Institut Teknologi Sepuluh November.

Zhang, S. B., Sun, M., Cao, K. F., Hu, H. \& Zhang, J. L. (2014). Leaf photosynthetic rate of tropical ferns is evolutionarily linked to water transport capacity. Plos One, 9(1), 110. 